\title{
Heretics, Democracy, the Beyond
}

\author{
Kuangming Wu \\ Rosebush Professor of Philosophy, University of Wisconsin, Oshkosh, Wisconsin, USA \\ Email: Kmwu2002@yahoo.com
}

Received 25 May 2014; revised 1 July 2014; accepted 14 July 2014

Copyright (C) 2014 by author and Scientific Research Publishing Inc.

This work is licensed under the Creative Commons Attribution International License (CC BY). http://creativecommons.org/licenses/by/4.0/

(C) (j) Open Access

\begin{abstract}
This short essay first describes (in Part One) what the heretics are, pesky yet needed provocation from outside our "right" orthodoxy, and then details (in Part Two) the heretics in sections from A through I, which joyously ties up the entire survey of the heretics invincible, soaring cosmically beyond. Protesting heretics take hold of their criticizing selves, to invite us all to self-criticize, and so they are resented by the orthodox already right. Heretics are idios, lone "idiotic" and independent, to resolve two paradoxes of democracy. Many factual examples are cited, recent and historical, USA and abroad, to show how essential the brave heretics are, risking their lives to jolt afresh the orthodox status quo, to go beyond it. Heretics have their sociality; self-critical, they never err. Thus, heretics provoke us to go beyond us, going-beyond is living, and so heretics provoke us alive homo-cosmic.
\end{abstract}

\section{Keywords}

Heretics, Democracy, The Beyond, Orthodoxy

\section{Introduction}

This essay focuses on "heretics" "taking” (hairein) on themselves to spread their self-criticism, not on "heresy" set dogmas, anti-orthodox orthodoxy. This essay first describes (Part One) what the heretics are, pesky yet needed provocation from outside our "right" orthodoxy, and then details (Part Two) the heretics from A through I, which joyously ties up the survey of heretics invincible, soaring cosmically beyond.

Protesting heretics take hold of their criticizing selves, to invite us to self-criticize, resented by the orthodox already right. Heretics are idios, lone "idiotic" independent, to resolve two paradoxes of democracy. Many factual examples are cited, recent and historical, USA and abroad, to show how essential the brave heretics are, risking their lives to jolt afresh the orthodox status quo, to go beyond it. Heretics have their sociality; self-critical, they never err. Thus, heretics provoke us to go beyond us, going-beyond is living, and so heretics provoke us alive homo-cosmic. 


\section{Part One: Description}

The heretics protest to open out, negating status quo, and negativity is well-nigh impossible to capture definitively. Fortunately, they are salient in political protest, and so we follow political heretics to grasp them, extrapolated to understand scientific heretics (Part Two, H). We now pursue heretics in democracy.

We all want to be in the right, orthodox. Heretics are outside the "right," so they are beyond "us" in the "right”; we fight them-unpalatable. In democracy as people-rule in ancient Athens people contended with rulers. Western government is built on enmity against people, theorized since Locke and Rousseau. The title (Fortas, 1968) “dissent and civil disobedience” stresses society over individuals; here heretics are sadly relevant.

Hobbes and his gang, and Renaissance thinkers, incredibly scheme to produce fascist Leviathan against powerless individuals (Woolf, 1968). Even USA government founded to guarantee "people's inalienable rights” (Monk, 2005), irresistibly grows bureaucracy beyond control, to force minority individuals to virulently attack their Leviathan, e.g., Thoreau, Orwell (1956), Arendt (1951, 1958), and sporadically Emerson and Mencken (Lief, 1969; Rossi, 1966).

Actually it is individuals who need protection by big society, for three reasons. One, society is made of individuals; no individuals, no society. Two, individuals are fragile as thinking reed crushable. Three, only individuals of flesh and blood, not society of mechanical system, have conscience, soul of powerful society that owes itself to protect to prosper powerless individuals its soul-essence.

No wonder China declares, Heaven sees as its people see, hears as its people hear, yet "people” are a loose crowd. Chinese politics theoretically begins at people, to factually end in serial dictators, only to be overthrown by the blood of powerless people. Globally fascinating, fascism bundles people up under an autocrat collectivist (Woolf, 1969), in US-plutocracy to pan-kill people bloodlessly. Human hubris totalizes to suicide, ruining itself with people-Heavenly.

Power against people kills power and people who are the be-all and end-all of early China's political climate, in “people-rooted ethos 民本思潮” of people-centrism, populism (not people as rulers), people-based-principled government of unconditional care for common folks. Mencius pointedly declares, to repeat, "Heaven sees and hears as/from 自 'my’ people see and hear” (5A5), for "People are precious; divinities [ideologies] are next; rulers are slight” (7B14) (Chen, 1976).

It is in this populist ethos-milieu that all dictators parade their propaganda as "father and mother of people 父 母官” (Waley, 1982), and to this ethos that all popular protest uprising appealed as their core standard-principle; around this populism all bloody tragedies in Chinese politics revolve. Such astounding tragedy is true all over the world, but only China has noted it as originated in populism, though its rulership itself has repeatedly violated this ethos to harvest continuous pan-bloodshed.

Thus, paradoxically, populism appears as king precisely in its failures. Doesn't this failure mean that populism is royal heresy beyond orthodox politics that politics cannot mock? It is Heaven that sees and hears-and shows - as its people see, hear, and show, and Heaven is beyond orthodox politics, as plain folks are one with Heaven beyond human politics. Remarkable revolutions in South Africa reenact this fact (Chidester, 2007).

Thus, strangely yet intuitively correctly, the organized society feels the eroding threat at its base its people, as its powerless underling individuals “raise justice 起義” of communal happy harmony, to produce all-out “changes-of-mandate 革命,” revolutions, to overthrow the putative government powerfully looming over its people.

Thus powerless crowds of individuals are actually the all-powerful controllers over the powers over them, albeit no declared “sovereign”; “democracy”-people-power if not people-rule-is a misnomer, a whitewash over the oppressive government designed to soften to tame erupting popular complaints, a ruler-centered compromise. This settlement is irrelevant to the populist ethos-unconditional promotion of popular welfare-as the basis in China's politics, what China has been consistently violating, as other nations do (Maharaj, Kathrada, Tutu, \& Clinton, 2006).

Even in the USA that explicitly avows "government for the people,” its 19th century "populist party” was short-lived. Populist movement has never been popular even in the US; its civil rights movements have had to fight bloody uphill battles (Carson, Farrow, Kovach, \& Polsgrove, 2003), even today. "People’s government” is ironically beyond people. The government takes itself as legitimate “orthodoxy,” to resent to reject pesky "heretic” protests, but unsavory "heretical” people always correct or overthrow “orthodox" government.

Ironically, "heresy” originated in the Greek “hairesis,” royal military town-taking (Kittel, 1964), to somehow 
turn taking oneself, choosing socially deviant views, to be unorthodox, "idios," alone independent (Woodcock, 1966), and criticism offends. Still, as an unexamined life is not worth living, so no-heretic society collapses into lethal orthodoxy. The heretics pester to warn their society, risking their lives-Socrates, Jesus, students at Tiananmen -insisting that their social "irritation” heals society's fatal smugness, to adopt populist polity as its life.

Ominous "orthodoxy" can also originate in an authoritative individual, a ruler, decreeing his idea for people to follow (Schenker, 2014); "heretics" are lone exceptions to majority, either autocrats dominating people, tycoons of plutocracy, legislative heretics lethal to people centrism, or protesting heretics of warnings moral (Socrates, Confucius) or political (Paine, Thoreau). This essay considers protesting heretics, detailed below.

\section{Part Two: Details}

A heretic "takes" oneself by one's choice against overwhelming society. This simple description has seven ramifications. One, one who takes oneself is idios, idiosyncratic and alone; "foxes have holes, birds have nests, but the Son of Man has nowhere to pillow himself." Two, this idios person appears "idiotic," insane-as Jesus was to his family, Paul to his ruler-yet literature praises them as revolutionaries (Johnson \& Adelman, 2008; Erasmus, 1979). Three, one who bravely takes oneself risks being overtaken by oneself, to become off-centered, eccentric. Eccentricity and insanity are hard to tell apart.

Four, resolutely choosing oneself can be a "genius," a genie-haunted individual; Socrates was "daimon"haunted. By arch-demon Beelzebub Jesus was said to cast out demons; Gerasene demoniacs recognized him spirit-haunted. Confucius was ridiculed by "insane people," who were prominent in Chuang Tzu's writings; Socrates was taken as eccentric. They are demoniacs or sages, or both. Five, "insane heretics" roam alone, as Gerasene demoniacs haunted graves. Six, the heretics' community would not be totalitarian. So far we have had six ramifications of heretics.

\section{Ramification No. Seven}

Here is the seventh ramification of the heretics. Heretics' "democracy" is not tyranny of the blind majority but rulership that protects the minority of "one's own," the privacy of individuals who prefer to be left alone to make "mistakes" of abortion, homosexuality, and treasonous protests against war, even during the war. These heretics live under community-laws protecting the "privacy of individuals," fragile, facing protesting the tough irrational social "royal force" from Socrates and Jesus' days till now (Freud, 1930). Such protest is patriotic.

Hobbes tried to control individual threats, never social suppression of socially harmless individual thoughts, individual "heretical" sovereignty (Dershowitz, 2005); his failure spells the ghastly world history. The heretics protest, not Hobbes' own freedom of self-expression but his self-expression that destroys his self-expression with all others. Heretics need not give up individual sovereignty for collective cohesion (Hobbes), but simply accept the common pact to promote individual sovereignty, the new "social contract" that nestles individuality to gently nourish bruised reeds of heretical ideas.

This is a federation of sovereignties of individuals. Biko the lone protestor of apartheid said, "The most potent weapon in the hands of the oppressor is the mind of the oppressed" (Biko, 2002: p. 774). We point admiringly at him, saying, "The most powerful weapon of the oppressed is also their mind-as yours!" So, such mind is the most powerful weapon either way, depending on the oppressed deciding how to set their mind, to allow the oppressor control it toward his "orthodoxy," or else use their mind toward independence. The key against oppressors is the self-reflective mind that spreads "democracy."

The "by" in "government by the people" is the ever-vigilant heretic's scrutiny of the government of the people, alive in journalists' editorials, elections of officials every few years, and candidates' debates. Journalists Woodward, Bernstein, George Orwell, H. L. Mencken, and Bill Moyers (2005), expose moldy social injustice to the public sunlight.

Now we are readied for seven results in pesky essential heretics, 1) gathering heretics, 2) resolution of first paradox of democracy: people as ruler-ruled, and 3) resolution of second paradox of democracy: people choosing autocracy, 4) many democratic coalitions, 5) liberality as liberation, 6) why bother?, 7) science-heretic, science-orthodox, to reach $\mathrm{H}$. pesky heretic, joyous invincible, to conclude this essay.

\subsection{Gathering Individualistic Heretics}

Can individualistic heretics gather into a community? If heretic is idios private-separate, then heretic "one" 
cannot mix with "many” whatever. Let heretic be idios as individualistic "one’s own," and a community of respect of individualities emerges to cross-fertilize "one's own" insights. Heretic's "one's own" is self-chosen selfcritical, critical even of one's own view as "other's." Criticism cannot be criticized without endorsing it, endorsement bespeaks togetherness, and self-criticism thus spreads into self-critical community, as true democracy.

\subsection{Resolution of the First Paradox of Democracy: People as Ruler-Ruled}

Democracy is people-sovereignty but remains ruled. This paradox is understandable—resolved—in being young. To behave as above is to be fresh mature, typifying youth, to characterize democracy; USA is ideally a "young nation" of amicable rebels, gentlemanly independent, as Confucius was a "gentlemanly princely man" protesting princes wayward tyrannical; princely gentlemanly, heretics keep USA young and democratic.

Still, gentlemanly-ness is persistently risky at compassion for everyone. Jesus left 100 sheep of orthodox platitudes for one truth of compassion, lost in pain, "until he finds it" compassion lost. So, despised common folks flocked to Jesus; their flocking comprises democracy.

"You come too" (Frost, 1975) called Jesus to the orthodox as he ends the parable of the prodigal son to complete "the persistent shepherd," both told to the orthodox who, offended, killed him the youth heretic. Compassion composes democracy, government of compassionate heretics for the neglected oppressed, mixing with no elite orthodox. Such compassionate heretics thus resolve a "paradox of democracy" government by the people who are the ruler (ruling principle of government) and the ruled (protected to be free), not "demo-archy" but "people-power" of lone protesters.

Sadly, people are easily lulled into "democratic orthodoxy" a monster. Half of Americans voted for the president whose disastrous blunders had widely been publicized in official channels and by open fair scholars. People's four typical sentiments at the time were: one, he can handle the situation, having been handling it so far (despite his disastrous mishandling). Two, he is trustworthy, doing what he says (despite his inflexibility to disasters). Three, "I am uneasy but I vote for him," rallying to "our familiar boy" in popular impression (actually he made USA much less safe). In this way, herd-mentality makes election a demagoguery-competition (Herbert, 2004).

Four, all stems from people's gut loyalty to the grand tradition, unshaken by one rotten apple in the grand barrel. Whatever our ruler does is of course correct; any contrary fact is enemy's propaganda. Here is orthodox "honor" in comfort, "foolish consistency" in accustomed conventions, "the hobgoblin of little minds" (Emerson, 2000). No factual evidence changes mind; change is painful inconsistency; rather steady descent into disaster than venturing new prospect. Their smug laziness killed Socrates and Jesus, ignored Confucius, and turned around to enshrine all three as "our orthodox tradition."

To err is human, to mend, sagely; "Mistaken and not mend it is mistake indeed!" (Confucius 15/30). "The ruler's errors are like sun/moon eclipses; the world sees them. When he mends, the world respects him." (Analects, 19/21) "Ancient ruler, once mistaken, mended. Today's ruler, once mistaken, not just continues but makes excuses” (Mencius 2B9). Socratic heretics today urge the orthodox to mend (Diamond, 2004), who yet have the divine right to be divinely right in "preemptive unilateralism" its "tiger" to bully heretics; orthodoxy then fears to dismount it that gets hungry!

Another horrendous example is Mao Tse-tung, who initiated "Down with Confucian traditionalism" in people's name, promoted the writer of protest Lu Xun and persecuted him, and "Cultural Revolution" stiffened into "orthodox People’s Republic of China” to ruin democracy (Starr, 2010); the heretical students at Tiananmen offended all this orthodox debacle, as common folks were also silenced. Traditionalistic orthodoxy dies hard in our horde instinct to be "in the right" among the majority "in the right."

People "group think" to lull into "no think," to stay put in the status quo in "consistency," into depraved "moral rectitude," in turpitude to ruin all. Pax Americana breeds dictators. People need jolts of heretics who gadfly-sting them, risking swatted dead; people had to rise to kill Socrates-gadfly who stung them awake. Socrates succeeded at stinging them with his death, as did Gandhi, Steve Biko, and Martin Luther King, Jr. These heretics are true democrats, ruled to rule rulers into right.

\subsection{Resolution of the Second Paradox of Democracy: People Choosing Autocracy}

Heretics' self-critical choices dissolve another "paradox of democracy," that it can indifferently choose dictator- 
ship to kill it. Such choice is due to people's inability to see through dictator's cover (Waley, 1982), to con them into cowering under dictatorship. Do we see USA today here? Democracy of self-criticism dispels people's democratic devastating choice of dictatorship. This is how it must happen, says the heretic.

In protesting their own pet ideas, heretics protest their beloved government that is one's own family (China) (Mencius 1A7, 4B20), oneself writ large (Socrates) (Barker, 1958; Locke \& Laslett, 2003). This government differs from Hobbes', Paine's, and Thoreau's to justify more protest, for here government is not contracted ad hoc but spontaneously extended from oneself and natural family where each member is born to grow into oneself, never into comfortable big government!

Thus common people's protest is innately telling to the family their government, to justify the "change of Mandate” (革命 ke-ming) people's revolution, to “raise their Right” (起義 ch'i yi). Such uprising of veteran heretics the persistent peoples has been horrendously effective in the bloody history of Chinese politics. It is the Confucian-Mencian rationale behind Lin Yutang's insistence on the radical effectiveness of China's public opinion and "journalism" (Lin, 1936).

Significantly, Mencius and American Declaration of Independence share divine rationales for the government for the people (Mencius 5A5) and people's inherent right to revolution when dictatorship opposes human independence (Mencius, 1B8). Blacks with conscientious whites made the irresistible heavenly forces, welling up from souls; with nonviolent singing boycotts, they forced the reluctant Congress to sign the Civil Rights Act (1964). The rest is history, of the "minority's" continuous popular protest (Carson, Garrow, Kovach, \& Polsgrove, 2003).

Normative protest has historic seriousness in China. Confucius wants (12/11) "the ruler be ruler, the minister, minister, the father, father, the son, son," to live out what we profess, the necessary human condition, which is also the basic criterion of the historian's judgment. Ministers failing to duly prosecute persons for assassination amount to being assassins themselves; vassals behaving like king commit regicide, death-punishable. Thus Confucians the grassroots heretics insist. Luckily, Confucius and Mencius did not die of their protests as Jesus and Socrates did.

Here are stunning facts of heroism in normative vein. Three brother-historians one after another braved executions by their lord who assassinated his lord, to record in five words that cost their lives, "Ts'ui Chu assassinated his ruler 崔杼斌其君.” Their bravery made their lord relent, to relieve the last execution to allow the record to stand (Hsiang, 2007). Their lone historic protest continues today; countless young students, nameless, defenseless, stood erect against their government's tanks to defend their nation. Tiananmen Massacre, June 1989, executes Democracy of Heretics against irrational orthodoxy of their nation.

Are these youths any different from those brave historians executed? Are these youths any different from Socrates, a lone heretic, aged, ageless, and penniless, defying his beloved government to defend his "beloved Athenians" against their self-deception? The heretics unceasingly self-examine to criticize their government, to create true democracy their eternal nostalgia.

\subsection{Many Democratic Coalitions}

Society demands "sociality" — conformity, docility—from its members whose self-choice opposes it. Not "charming heretic" but "graceful nonconformist" is feasible, desirable for survival, and effective of self-choice; self-choice can be made genially, gracefully. For social "conformity" the individualists can offer geniality; for "docility," they offer grace and tact. Civility, grace, and genial tact compose loose cordial coalition of "friendly foes," civilly disobedient, nonviolently protesting (not "revolutionary sedition" if social reform can be effected without it); they are the heretics' virtues.

Spontaneous "democracy" from grassroots individualists is each culturally coherent, naturally distinct in form in sentiment. Imposition of one democratic polity (US) onto another (protesting Iraqis) is "imposing democracy," a democratic dictatorship, a monster. In "democracy," people gather in distinctive musical unities. Each individual note is special essential. Each communal composition is a distinct family; each community depends on each member to exist, who is enabled to live head up as "heretics together." "Musical family" is the Chinese ideal of true government. "Government by music" and "government as family" were in vogue in classical China. Chi, Lien-k'ang compiled and translated Theories on Music in Confucius, Mencius, and Hsün Tzu, Musical Theories during the Two Han Periods, and Data on Music in Mr. Lü’s Chronicles (Lü, 1963).

Such Utopia actually has “no place,” but Hobbes’ Utopia has none, either (Butler, 1872; Johnson, 1968). We 
would choose the heretics' over Hobbes', as nothing should be more cherished than choosing Utopia "of one’s own." If irritated society brands this Utopia "heretical," shame on the society whose mission it is to promote "heretics," free individuals thinkers.

Heretic's idios, idiosyncratic self-protest, lone unpopular, is a dynamics to democracy. Marginalized recluses are fountains of sociality. Voltaire's "I disapprove of what you say, but I will defend to death your right to say it," seriously defends anyone's expression of any opinions, never casual. He adds, "Liberty of thought is the life of the soul” (O’Brien \& Bartlett, 2012). Nothing is more crucial, and nothing is harder, socially and individually.

"But these heretics must be always right to bravely criticize society. How can such unpalatable heretics be always correct?” Heretics' self-critical sting cleanses themselves and others; Socrates was self-critical to death, even to obeying the bad law, as he self-scrutinized in Crito! (Schenker, 2014). Criticism of USA must itself be criticized lest turning "anti-orthodoxy orthodoxy," a monster un-stomachable. Beware, fixated "liberals"!

We would now criticize Paine (1995) who in "Common Sense" (p. 6) condemns government produced "by our wickedness by restraining our vices, a punisher. Government even at its best is a necessary evil; in its worst intolerable, and we furnish the means by which we suffer. Government, like dress, is the badge of lost innocence; were the conscience clear and irresistibly obeyed, man would need no other lawgiver; but that not being the case, he finds it necessary to surrender a part of his property as a means to protect the rest; out of two evils we choose the least."

Applauding his protest, we follow him to protest his protest. He said government is a "necessary evil." If "evil," why does he not just abolish it? It is "necessary" due to our inability to follow conscience, he said. Why, then, not protest our inability, not government evil beyond repair? He acquiesced in evil government, vainly tinkering with it. Acquiescence defeats protest. Worse, his protest is based on conscience he fails to prop up. His protest in "Common Sense" is based on defeat of common sense; his protest defeats itself.

"Winning others has power; self-winner is strong” (Lao Tzu 33). A heretic "wins oneself as others," taking on one's ideas as we just did. I can afford to open to opponent who is myself as another and myself in another; Voltaire can afford to defend his opponents' right to express ideas, while examining criticizing them. Criticizing criticism joins it; thus criticism is always right. Accommodating opposing ideas until fracturing the self ensures being right, always.

Only liberals can write "the end of liberalism" to promote liberalism; only self-critical philosophers can write "after philosophy” to annul to animate philosophy (Baynes, Bohman, \& McCarthy, 1987; Lowi, 1969). Self-critique vitalizes thinking camaraderie; self-criticizing liberal-heretics discover comrades. Facing one corner Confucius raised, his disciples must produce three more for the square of truth (Analects 7/8, 5/9), to spread interindependence. Self-protest makes me disagree with my reasons, to inter-disagree into democracy in inter-selfcriticism, and so can never err.

\subsection{Liberality as Liberation}

"Being correct" corrects oneself-as-opponent, a dynamite of self-correction on the reformative exploding. It is thus that one is not tied to a fixed self; this "not" is the élan of heretical protest. Heretics are independent of their selves, liberated from set ideas, from bigotry. Such is the soul of liberalism. As liberty of thought is the life of the soul (Voltaire), so liberalism is the soul of democracy.

In contrast, "orthodoxy" is already correct, automatically infallible; have we heard a cocksure president admit mistakes? Orthodoxy is illiberal, self-conservative, self-sealed bigotry that means "wrong," and so orthodoxy practices its betrayal, "not-orthodox," pan-hiding its self-betrayal. "Outside warning" on this self-betrayal irritates orthodoxy as "liberal heresy" its enemy, unaware that "heretics" bring "orthodoxy" out of its rut of unorthodoxy, under cover of "orthodox democracy."

Democracy among unwary dolts spells tyranny of mob-majority, swayed by their "inalienable right to happiness" of raw greed under dictatorial demagoguery. "Democracy" is "the worst form of government" (Plato, Churchill), in "group-think" of the uneducated. So education is its cure, "psychagoge" (Aristotle, 1982; Plato, 2012), soul-leading by allurement (Confucius), in the "soft power" of persuasive attraction (Nye Jr., 2005). Public education are soft heretics to people in conscientious TV in courageous journalism. Watergate debacle came, tobacco industries toppled, and Enron and Japan bubbles burst.

Finally, history's contingency downed emperors, Nero, and Hitler, directed by common folks who know where the shoes pinch; it is "journalism in China” (Lin Yutang), Schell sees "hidden democracy" in China; Zinn 
is today's born-again sage on people's power to shape our historic destiny (Schell, 2004).

So, the three heresies are soft journalism, education, and contingent history, soft winds of "democracy" blowing away power-greed. "To winds of virtuous ruler, people the grass bends" (Confucius 12/19). In democracy people-power, people are the ruler, while remaining the grass bending to the virtuous ruler-wind. "Virtue" is human power assessing, bending only to winds of thoughtful journalists, officials, and scholars, not to winds of their desires; most US journalists and scholars in 2004 were anti-Bush, and half US people were pro-Bush. USA still totters after over 200 years of democratic struggles.

So, the terrible fact is that democracy is fragile; the "inalienable right to pursue happiness" slips into license for rifle, money, property, abortion, ecological disaster, etc., while bending to winds of money-power. This is not to ban rifles/properties/abortions, as totalitarianism would do, but to urge each of us to be responsible to our rights to them, never to abuse them. Such counsel is difficult to obey, and the difficulty tells of the fragility of democracy. Disaster peculiar to democracy is precisely its genius of people's right to rulership by voting, however uncritical, ignorant, and swayable, as money uses the ill-designed Constitution to "direct election."

Democracy is a gathering of independent heretics watching over policy performance; orthodoxy has only personality, not policy or performance. If he is "one of us," whatever he does is "moral," and orthodox attacks on opponents are ad hominem, "He is untrustworthy, so whatever he proposes is bad." The foremost factor beyond Iraq and unemployment is the "moral factor"; "tripping over his own words" shows not low IQ but a man of "moral action, not of empty words" (Blake, 1998). All this is an incredible "winds" of "public relations"! No less incredibly, the American public bought it!

Thus complaints must emerge to save fragile democracy swayable into liberty-robbed dictatorship, post-voting or pre-voting. People's complaints promote individuals' inalienable rights, stampede-able by the majority under spell of "orthodoxy." This sad fact forces us to say that majority votes are less crucial in democracy than individual heretics. To promote individual idiosyncratic privacy is the society's priority; we must choose to criticize, risking being branded "heretic," "insane," "idiotic," and worse. "Heresy" is the only way to true democratic humanity.

\subsection{Why Bother?}

"But why bother with heretics and orthodoxy?" Answering this protest hits the root of above. "Orthodoxy" is not a treasure-box safely sealed; it is authentic living. At age 115, the world's longest lived Dutch person was asked about the secret of long life. She said, "Breathing." Life unceasingly in-breathes outside cosmic air (Mencius 2A2).

Life-authenticity breathes to deal with outside air; "orthodoxy" is a verb pushing toward orthodoxy by accepting outside "heretics" self-criticizing, to point the society to outside its status quo; this pointing-outside pushes us to real orthodoxy. It is a matter of social life and cosmic breath. We must "bother with heretics and orthodoxy" on pain of living death. Obnoxious heretical push-out is an inherent élan to the Beyond, making life truly alive. The Beyond is often an unwelcome heretic, yet always needed as breath. A poignant closed-in example comes to mind.

\subsection{Science-Heretic, Science-Orthodox}

An actual example shows how the supposedly open-minded scientists actually close-in to fight heretics. When Dr. Alexander a well-known brain-physician came back alive after 7 full days in coma, and wrote his heartfelt report on his journey to afterlife (Alexander, 2012), many fellow physicians rise up to criticize him as fraud (Nuland, 2000). Not having experienced coma, not brain-scientist having taught at Harvard for fifteen years, some not even brain-doctors as Alexander, these "medical scientists" accuse him as a pseudoscientist.

Another scientist simply identifies physical components of human life as the only life-components-life as nothing but physical-and appeals to "science" that sees only physical stuff; identification and science intercause to strengthen his conviction, to enunciate human life as all-physical, ignoring any view or argument for beyond-science beyond-physical, even pitying them as "obsolete, superstitious." Tears are just chemical liquid secreted from cavities in the skull. I say, tears are also feeling-stuff; he says "feeling" is located in the liquid. I say, feeling-location is not feeling; he just stares at me. Music is just horse-hair scraped on cat-gut into sound of mathematical ratio. Any "music" beyond this is vague and nonexistent. It is as simple as that! This is how neat "only" is, how messy "not only" is. He is a brick wall to anything beyond-physical, to cipher scientism ortho- 
dox-dogmatic.

Jesus is right, saying people would not accept the Beyond even if someone came from death, if they do not accept the prophets (Luke 16:31). Jesus tells us no why-not, though. Is it because it is too much pain to twist the "scientific mind" toward beyond-science, and so some scientists deny beyond-science wholesale? Accepting the Beyond is faith to require defying our reasoning, too much to ask from us proud "scientists." We would rather bury our orthodox heads in the scientism-sands of this world, but doing so dooms us, for we would soon leave this world to face the Beyond, accepted or not. They would say they would be nowhere after death, as if they know! This again manifests them burying their dogmatic heads in the worldly sand. Doomsday is not just full of fire and brimstone (Genesis 19:24, Revelation 19:20). As spring dawns, trees alive (Alexander, Taylor) blossom in white tender, pink faint; others remain stubborn barren, dead. Spring is the Day of Judgment.

Unpacked, "pseudoscience" argues that veracity of the report on the reality of beyond-life hangs on knowledge of this-worldly science; Alexander the prominent brain-scientist knows no science; so, his report is a hoax of pseudoscience. Not only are each step here false and the argument invalid, their own admission to "agnosticism" of afterlife, and their deducing denial of afterlife from ignorance, rebut their own argument." This invalidity is amazingly ubiquitous among some "medical scientists."

Such non-sequitur shows their intense distaste of afterlife beyond the reach of science. There is no dispute over taste or distaste, no room for rational argument, only argument-brawl. Obviously, beyond-science upsets their solid unmovable "Rock of Gibraltar" of science-orthodoxy, science-totalitarianism governing everything; its parallel with religious fundamentalism is uncanny. Science-fundamentalism is also obsessed with "correct science," closed in on it. Slightest deviation immediately incites hysterical rejection of "heresy." Now let us retrace our understanding here, to generalize it.

To begin, their non-sequitur is due to confronting a surprise report on things extra-ordinary, with its scientific vocabulary so twisted that this brain scientist was taken as knowing no science. As Paul was labeled "insane" for reporting the incredible resurrection of the dead (Acts 26:24), so Dr. Alexander's report on extra-brain consciousness is labeled "pseudoscience," i.e., insane. Facing his report on out-of-this- world, it would have been odd if it is not labeled "heretical" off this-worldly orthodoxy.

Less dramatically but no less extraordinarily, Dr. Jill Taylor, Ph.D., the neuro-anatomist, reported her rightbrain experience of cosmic euphoria as her left logical-cognitive brain was shut off by stroke (detailed in her left-brainy technical chapters), from which she took 8 years to recover before writing a book on the experience (Taylor, 2009).

"My stroke" blocked left brain into deep inner peace of the right brain, at one with the cosmos. This is her "insight" innate. Both books by two prominent brain-scientists are rare human reports so precious, both identically urging us to choose inner deep peace at one with the cosmos.

China says, "Back off a step, ocean wide, sky vast." Dr. Taylor says, "Back off a step into right brain, at one with cosmos ocean-sky vast" (Croce, 1970). She forgot to add that we can and do keep our brain our person to back off into cosmos, and need not vanish into Nirvana that "blows-off" the self as empty desire; she misnamed her cosmic bliss "Nirvana” (pp. 116, 242, 176). Taylor with Alexander are right-brainy heretics of "inner deep peace" vastly cosmic. Now let us return to Alexander.

Alexander's whole show is a dramatic rerun of Plato's famous allegory of the cave (Plato, 1945). A fellow prisoner among those in the cave happens to rise up outside to see the Sun of Ideas, and comes back to report it. His fellow prisoners rise up and kill him. It is so sad a story about us refusing to go beyond our status quo stale and comfortable.

A mere aspect of life physical essential is conveniently identified as all life, and now life is a tight physical system in flickering candlelight of scientific reason; it is a cave, this world. Their fellow science-prisoner Alexander then happens to be coma-released into an ex-science afterlife realm, to come back to report in their scientific language its fabulous brilliance. This report throws their orthodox all-governance into confusion quite unmanageable.

Detesting his annoying disturbance, they must kill his heresy into pseudoscience. Alexander's afterlife is their Beyond on the other side of the grave, an intolerable heresy devastating their systematic orthodox "cave" of scientism pan-physical, all on this side of the grave. Soaring to Beyond-science is pain excruciating, shattering into chaotic pieces their ironclad government of this-worldly science. Growth beyond this-worldly "adulthood" is pain heretical intolerable.

We feel their horrendous ire of orthodoxy pounced on this irritating heretic. No orthodox alive wills to believe 
in anyone back from beyond-life beyond-orthodoxy, Jesus assures (Luke 16:31). Chief priests the orthodox plotted to kill Lazarus back alive (John 12:10), an unwelcome heretic beyond-life disturbing orthodox "science" of this world. In short, we agree caution typifies science. Heretics caution science, "Can't caution extend to scientific verification, extend to verified-falsity? Isn't this extension 'scientific'?” Heretics thereby restore science from science-orthodoxy unscientific.

Let us now push the heretic move on science into poetry. Poetry is ideas in rhythm as life is in heart-rhythm. I turn physics into poetry as I arrange alphabets into a poem. I must learn alphabets to write a poem, but no one stays in alphabet; I must learn physics to write poetry of life, but no one should stay in physics. Physics is a passage to joy of life poetic (none stays on highway). We may make an emergency roadside stop, but never stay there, as even Jesus' parable of the Good Samaritan shows (Luke 10:30-37). Taylor shows how to write life-poetry with physics of our brain in her Chapter 19 on how to find deep inner peace (pp. 168-184).

Poetry is our mother tongue; all prose is poetic, as all expressions are rhythmic (Croce, 1970). Music is the rhythm of cosmos our nature (Croce, 1970). So, music is the rhythm of poetry jumping around in ideas in sounding. Poetic jumps are natural, systematic with no explicit system. So, such jumps vitalize us jump-alive into leaping kids singing rolling poetry in their tongues. We cannot live without music in poetry as kids alive in it. All this is the womb of logic, argument, science, ethics, and philosophy.

The reason is obvious. Music in poetry mobilizes our whole being. This beauty that convinces is the womb of truth pursued by science, argument, and philosophy. Beauty is the womb of truth that nods at "good" to work-act out in life, as ethics aspires to. As China says, "truth, good, beauty," beauty is the supreme Child Queen of all. Religion chants an ultimate ode to this Child Queen shouting in all smiles. Joy, joy, joy!

Now, in this light, let us put the woe of scientism another way. We get into trouble because we tinker with powerful poetry. Poetry rhymes in ideas rhythmic, as kids bubbling up in babbling talks. Kids are poetry-alive so full. Poetry smells kid-fresh to kid-refresh us, jumping in ideas to jump us alive. All Presocratics wrote in poetry to begin Western philosophy. Pan-physics-scientist can take Dr. Alexander as a poet, to turn physics into poetry beyond life, as our brain synthesizes intuitive right with logical left. To Taylor the brain scientist, pain is hereticpoetry, even "stroke" she benefited (Taylor, 2009)!

This is poetry total, cosmic, and invincibly alive as kids with kids. Poetry-as-kids begins afresh to re-begin physical life, what Alexander's (2012) book, "Proof of Heaven," means; the very title is poetry. Here, "Is what it says physically real?" is moot, as "beginning" is beyond physical proof to begin physics. The book proves nothing to begin all, poetic homo-cosmic.

Science can be used to gauge beyond scientifically gauge-able, e.g., science cannot explain why it can explain. I can answer what science means to lead me to my inability to answer what beyond-it means. Asking "what it means" catapults me beyond meaning, while kids the beyond-meaning pursue "what it means." As I cannot answer what an "infant" means, she turns me into infant-beyond-me in infant wonder, eager to learn, revering those who know, to play to grow as Child Queen.

\subsection{Pesky Heretic, Joyous and Invincible}

Here is a sober fact. Mencius, Jesus, Dr. Alexander, and Dr. Taylor all say—insist on—two points. Deep inner peace is just a thought/feeling away (Taylor) deeply embedded in our heart not-bearing people's pain (Mencius), and this peace is unconditional love homo-cosmic (Alexander, Jesus). And strangely they all fail to convince "us" who just laugh them off as deluded, unaware that we ourselves may well be deluded in dogmatically refusing to accept them-as-real.

Scientists proudly announce, "We are constantly making progress," unaware that "constant progress" indicates "constant imperfection"; caution is thus the true scientific attitude, not confidence, much less pride. Progress improves; improvement betters wrongs; wrong is imperfection. So, progress improves on imperfection; constant progress shows constant imperfection. So, what scientists disprove, or cannot prove, commands no denial or condemnation but agnosticism, i.e., admission of ignorance. What Alexander "as scientist proves" is also to be taken with cautious agnosticism. Such is how heretics alert the scientists against forming a clique sacrosanct, "Our science, right or wrong," no, "Our science, never wrong!"

"There are two ways to be fooled. One is to believe what isn't true; the other is to refuse to believe what is true" (Kierkegaard) (Alexander, 2012: p. 129). This means, not that we must accept Alexander and Taylor as "right" (lest we are fooled), but that we must not reject them as "wrong" (lest we are fooled the other way). It is 
agnosticism, a tricky art of resolutely sensitively to suspend any final judgment; and it is so hard to suspend judgment. A job of heretics is to warn us of dogmatism either way, to accept or to reject, urging us to practice this tricky art of "blank" suspension of judgment.

All dictionaries say "miracle" is awe, i.e., wonder, marvel, to indicate things beyond expectation. Science pursues things beyond common expectation, cautiously. Science never agrees or disagrees categorically, only probabilistically. That is "progress" in exciting "imperfections." All this deletes scientific condemnation of superstitions, tyrannies, even abominations! Scientists pore over urine they call "specimens." Scientists should also pore over superstitions, actually. None does. No one else does! Scientists are miracle-workers! But they do not know so, but are just proud of themselves orthodox. So, Mencius, Jesus, and Drs. Alexander and Taylor are "heretics" hitting the brick wall of the orthodox denial. The brick wall can crumble in two ways. One, the orthodox can undergo their own unbearable pain seeing pain of people and go through near-death-experience as did Doctors Alexander and Taylor the initial firm deniers. Two, the orthodox can be melted by the child's disarming innocence. "What's your name?” "I don't kno'. Mom kno'!” There! That's motherly inner peace homocosmic beyond him here now, not a Zulu far, shouting "O mother! I'm lost." "We say 'far away'; the Zulu has for that a word which means, ' ' 'There where someone cries out, 'O mother, I'm lost'” (Buber, 2000: p. 31). Beside the Pollyanna orthodox, pesky heretics in this way warn us persistently, realistically. As all truths are halftruths (mathematical logician Whitehead warns), so all tasks are half-finished (Price, 2001); as all truths are then half-false, so all jobs are unfinished. As nothing is perfect, so all things are ever on the way perfecting, bit by bit. Things are always under construction, adjusting by increments. Heretics hassle us this way, as life is a hassle, telling us that things are always in whirlpools unsteady, and we must do our best to make ends meet different way, as each different occasion arises.

Under such unpalatable circumstances, ebullient heretics "back off a step" to hairein-take hold of the core-self (Kittel, 1964), and “ocean wide, sky vast” (Chu, 1995). Now we can listen to this brave heretic's gutsy selfdeclaration. "Allow me to confess to my thrilling ideals, in six points:

One, I understand to understand, to understand the how, what, why of things, always.

Two, I learn even from Hitler, from Nero, from Tojo, all of whom I deeply detest.

Three, I never brush aside as fraud, false, wrong, and/or non-existent, any abominable superstitions, contradictions, anything. They are my chances to change to grow-in them, out of them.

Four, the Beyond is my motto, always going beyond where I am, on my way.

Five, my opponents are my critics, to criticize me and them, as I always say, "Yes, but."

Six, my two "enemies" are fixation and orthodoxy; I am on my way, to better my best.

Now, of course I always fail the above. My failures pick me up to press on. This is why my ideals above are thrilling — precisely in my failures. It is “'pan-iconoclasm', stressing 'pan-' that knocks me down.”

Such confession bespeaks the invincible resilience of heretics the tumbler, down in up, down to up, up in down, ever alive unfinished, on their way to the Beyond-now. Such is the heretics' power alive pressing ahead, refusing to stay "orthodox" comfortable, dead in a rocking chair. It is this unceasing power of heretics to ever disturb that vitalizes the élan toward being orthodox in gutsy authenticity, ever on the go. We call such tumbler bounce-back, "life."

The heretic continues, "I the heretic at my self-core prove the Heaven wider than whirlwind-ocean, vaster than thrilling sky far beyond.” All this while, heretics are warning shouting at us, sober realistic, jumping alive. Since everything is half-true half-false, things would not keep as they are. They are always fresh to begin all over afresh; staying put, they decay to vanish (Whitehead, 2001). Heretics at the forefront of things press ahead adjusting revolutionizing, never at rest. It is thus that, ever pesky beside stable orthodoxy, heretics at the self's inner depths are the undisputed Child King Zeus over all whirlwinds worldwide that have driven out Zeus (Lippmann, 1929).

Criticism is invincible, as criticizing it joins it, ever beside orthodoxy to keep it vitally orthodox, and criticism is unending as life is. Such is the heretic. Now we add that the heretic with critical invincibility is sheer joy, riding the rough crest of life-waves. "Ritual" is akin to arithmos, number (Merriam-Webster's Collegiate Dictionary, 2008: p. 1076); it is then the basis of science. And ritual is adaptation of ceremony (Oxford English Dictionary, 2001). So, science is our ceremonial ritual in change yet thought to be beyond change, as "ritual" is. Fame, power, and money are also our rituals, "eternal” ephemeral. Excellence is a ritual, one extreme of life's waves.

"Excellence" we want is elusive mysterious. Does it come from competition, enjoyment, leisure, early genius, or old age? Is excellence experience, reclusive, prominence, beauty, first, last, unusual, or usual? Thus excellence is all over always yet shifting, as ritual is. Isn't excellence a ritual, then? Heretics are outside excellence, 
enabling it to happen, critically. Now here is the other extreme, our ugly rock-bottom, evil in devil. The heretics handle it this way.

Would devil in evil get sick, pained, frustrated, and inflicted with what it inflicts on us? And we sneer it away; it is only fair. No wonder, devil hates ridicule, conquered by irony. Such irony reversal in pan-criticism is no ritual but heretics, in this world not of it, beside orthodoxy not orthodox, being naughty ironic even to heretics themselves, and so heretics are happy devil-may-care. Do we now see how such heretical joys are invincible? Heretics simply ride all life's waves between excellence and devil!

\section{References}

Alexander, E. (2012). Proof of Heaven: A Neurosurgeon's Journey into the Afterlife. New York: Simon \& Schuste.

Arendt, H. (1951). The Origins of Totalitarianism. New York: Schocken Books.

Arendt, H. (1958). The Human Condition. Chicago, IL: University of Chicago Press.

Aristotle. (1982). The Basic Works of Aristotle. New York: Modern Library.

Barker, E. (Ed.) (1958). The Politics of Aristotle. New York: Oxford University Press.

Baynes, K., Bohman, J., \& McCarthy, T. (Eds.) (1987). After Philosophy: End or Transformation? Boston, MA: MIT Press.

Biko, S. (2002). I Write What I Like. Chicago, IL: University of Chicago Press.

Blake, W. (1998). The Complete Poetry \& Prose of William Blake. New York: Anchor Publishers.

Buber, M. (2000). I and Thou. New York: Scribner Classics.

Carson, C., Garrow, D. J., Kovach, B., \& Polsgrove, C. (2003). Reporting Civil Rights. Two Volumes, New York: The Library of America.

Chen, L. F. (Ed.) (1976). Quick Index to the Four Books. Taipei: World Press.

Chidester, D. (2007). Studying Religion in South Africa. In M. E. Courville (Ed.), The Next Step in Studying Religion (pp. 129-46). London: Continuum.

Chu, Z. (1995). Chu's Complete Works. Tainan: Da-Fu Publishers.

Columbia University Press (2000). The Columbia Encyclopedia. New York: Columbia University Press.

Croce, B. (1970). Aesthetic. New York: Noonday Press.

Dershowitz, A. M. (2005). America on Trial. New York: Grand Central Publishing.

Diamond, L. (2004). What Went Wrong in Iraq? Foreign Affairs, September/October, pp. 34-56.

Emerson, R. W. (2000). The Essential Writings of Ralph Waldo Emerson. New York: The Modern Library.

Erasmus, D. (1979). The Praise of Folly, C. H. Miller, Tran., New Haven, CT: Yale University Press.

Fortas, A. (1968). Concerning Dissent and Civil Disobedience. New York: New American Library.

Freud, S. (1930). Civilization and Its Discontent. New York: W. W. Norton \& Company.

Frost, R. (1975). The Poetry of Robert Frost. New York: Holt Paperback.

Gragg, R. (1954). The Story of the Declaration of Independence. New York: Oxford University Press.

Herbert, B. (2004). Voting Without the Facts. New York Times, 11/8/2004.

Hsiang, D. (2007). Year Twenty-Five, in The Tso Chuan. Taipei: San-Ming Publishers.

Johnson, C., \& Adelman, B. (2008). Remembering Martin Luther King, Jr.: 40 Years Later. Life Books, New York: Time, Inc.

Johnson, J. W. (1968). Utopian Literature: A Selection. New York: Random House.

Kittel, G., \& Bromiley, G. W. (1964). Theological Dictionary of the New Testament. Grand Rapid, MI: Wm, B. Eerdmans.

Lief, R. A. (1969). Homage to Oceania: The Prophetic Vision of George Orwell, Columbus, OH: Ohio State University Press.

Lippmann, W. (1929). A Preface to Morals. New York: Macmillan Company.

Locke, J., \& Laslett, P. (2003). Locke: Two Treatises of Government. New York: Cambridge University Press.

Lowi, T. J. (1969). The End of Liberalism. New York: W. W. Norton.

Lü, S. (1963). Chi, Lien-k'ang compiled and translated Theories on Music in Confucius, Mencius, and Hsün Tzu, Musical Theories during the Two Han Periods, and Data on Music. Taipei: San-Ming Publishers.

Maharaj, M., Kathrada, A., Tutu, A. D., \& Clinton, B. (2006). Mandela: The Authorized Portrait. Kansas City, MO: An- 
drews McMeel.

Monk, L. R. (2005). The Words We Live By. New York: Hyperion.

Nuland, S. B. (2000). The Mysteries Within; A Surgeon Reflects on Medical Myths. New York: Simon \& Schuster.

Nye Jr., N. S. (2005). Soft Power: The Means to Success in World Politics. Boston, MA: Public Affairs.

O’Brien, G., \& Bartlett, J. (2012). Bartlett's Famous Quotations. New York: Little, Brown and Company.

Orwell, G. (1956). The Orwell Reader. Harcourt, NY: Brace and Co.

Paine, T. (1995). Common Sense. New York: Barnes \& Noble.

Plato. (1945). The Republic of Plato, tr. Francis Macdonald Cornford. New York: Oxford University Press.

Plato. (2012). Plato: The Complete Works. New York: Hackett Publishers.

Price, L. (2001). Dialogues of Alfred North Whitehead. Boston, MA: David R. Godine.

Rossi, W. (1966). Walden and Resistance to Civil Government: Henry D. Thoreau (2nd ed.). New York: W. W. Norton.

Schell, O. (2004). China’s Hidden Democratic Legacy. Foreign Affairs, July/August, pp. 116-124.

Schenker, D. (2014). Personal Conversation.

Starr, J. B. (2010). Understanding China. New York: Hill \& Wang.

Taylor, J. B. (2009). My Stroke of Insight: A Brain Scientist’s Personal Journey. New York: Penguin.

Waley, A. (1982). Three Ways of Thought in Ancient China [1939]. Stanford, CA: Stanford University.

Whitehead, A. N. (2001). Dialogues of Alfred North Whitehead (edited by L. Price). Boston, MA: David R. Godine.

Woolf, S. J. (1968). The Nature of Fascism. New York: Random House.

Woolf, S. J. (1969). The Nature of Fascism. New York: Random House. 
Scientific Research Publishing (SCIRP) is one of the largest Open Access journal publishers. It is currently publishing more than 200 open access, online, peer-reviewed journals covering a wide range of academic disciplines. SCIRP serves the worldwide academic communities and contributes to the progress and application of science with its publication.

Other selected journals from SCIRP are listed as below. Submit your manuscript to us via either submit@scirp.org or Online Submission Portal.
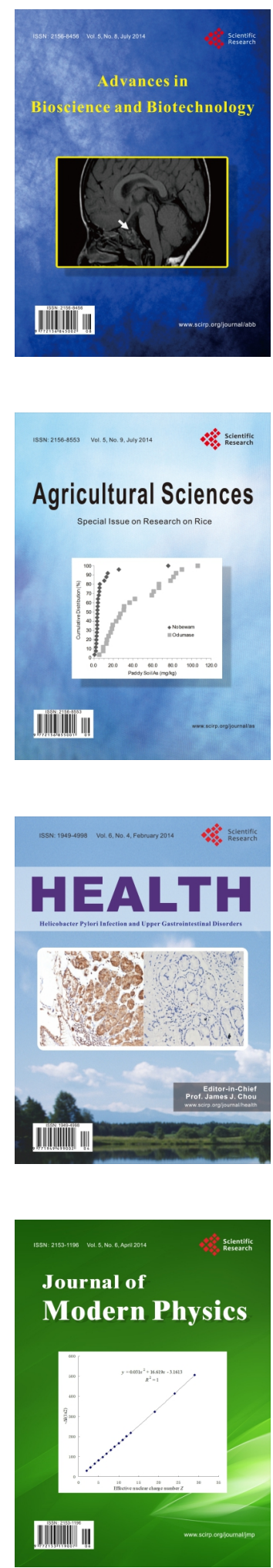
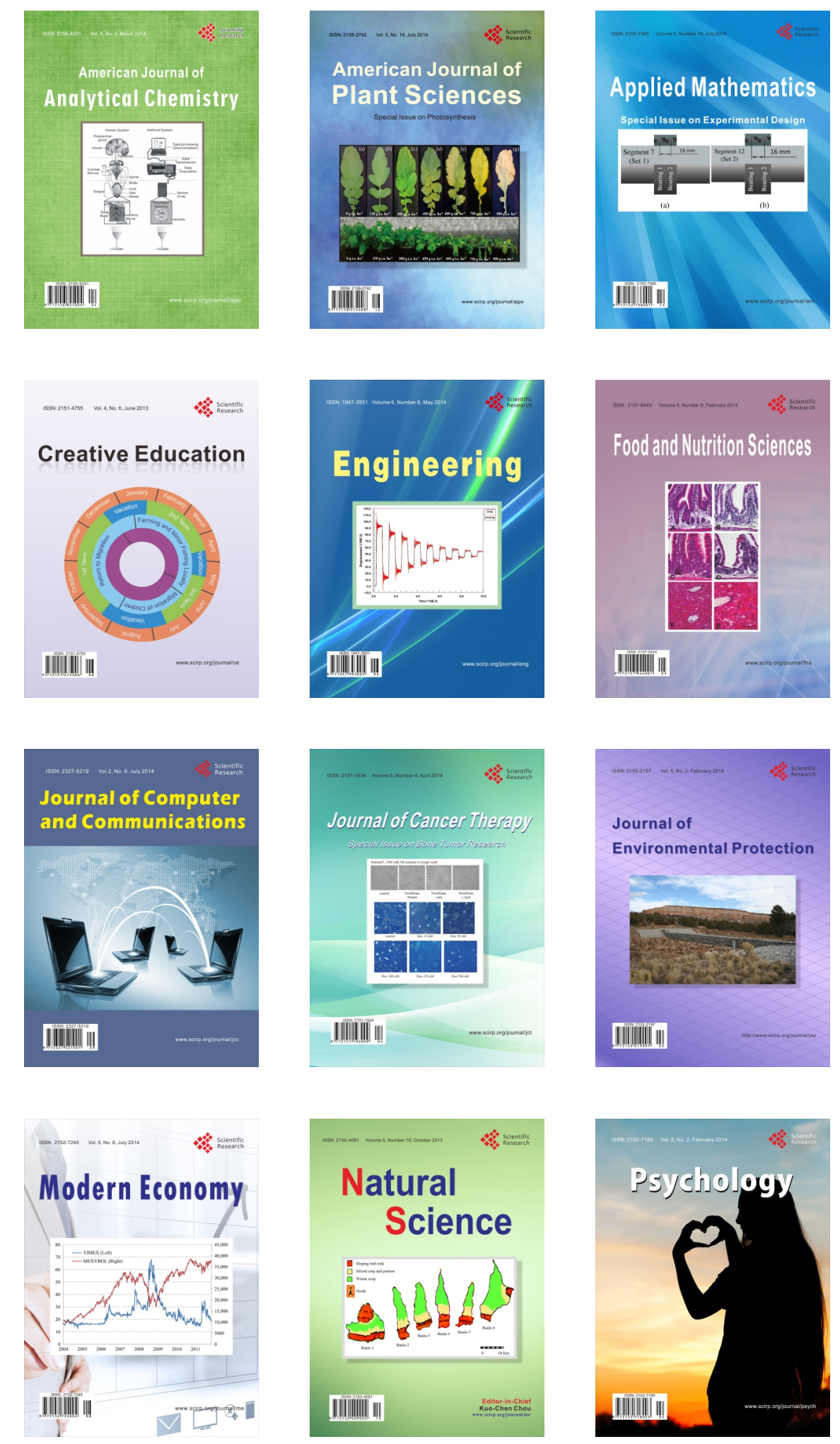